\title{
A Comparative Analysis of the Biological Parts of the National Curricula in Lower Secondary Education in the Czech Republic and Selected Post-Communist Countries
}

\author{
Jana Poupová, Vanda Janštová, Radim Kuba, Jan Mourek
}

\begin{abstract}
In the Czech Republic, a revision of the national curricular documents for primary and secondary education is being prepared and intensively discussed. The aim of this paper is therefore to contribute to the ongoing professional discussion and to select the key aspects of foreign curricular documents that may be inspiring for the Czech curricular reform.

In our study, we compare the concept of the biological part of the valid national curricular documents for lower secondary education (from the $6^{\text {th }}$ to the $9^{\text {th }}$ grades), the second stage of basic school in the Czech Republic, with five selected post-communist European countries, namely Estonia, Hungary, Poland, Slovakia and Slovenia. We focused on the following key aspects: a) the major characteristics of biology as a school subject (or the biological part of the subject "science"); b) specification and arrangement of subject matter; c) biology as a scientific discipline; d) didactic recommendations and requirements; e) the way of treating crucial biological disciplines; f) other criteria, such as emphasis on local regions or public engagement.

We consider the Estonian and Slovenian educational programmes to be the most inspiring ones, since they elaborate general educational objectives to the level of particular learning content and standards of knowledge. We also find the links to practical work and ICT and connections between biology and general competences very useful when using the documents in classroom practice. The Slovenian document offers an inspiring holistic approach to teaching of biological issues. The Estonian curriculum is a good example of incorporating local aspects, such as typical local ecosystems. The national curricula of both countries recognise biological knowledge and scientific literacy as being very important for the lives of the individual as well as for society.
\end{abstract}

Key words: biology, curriculum, curricular reform, lower secondary education, science. 


\title{
Srovnávací analýza biologické části národního kurikula na 2. stupni základních škol České republice a ve vybraných postkomunistických zemích
}

\begin{abstract}
Abstrakt
V České republice v současné době probíhá revize národních kurikulárních dokumentů pro základní a střední školy, kterou doprovází intenzivní odborná diskuse. Naším cílem je proto vybrat klíčové aspekty zahraničních kurikulárních dokumentů, které by mohly pro českou kurikulární reformu posloužit jako inspirace.

V naší studii porovnáváme koncepci biologické části platných národních kurikulárních dokumentů pro druhý stupeň základní školy (a odpovídající stupně nižšího sekundárního vzdělávání v zahraničí) v České republice a v pěti vybraných evropských postkomunistických zemích (Estonsku, Mad’arsku, Polsku, Slovensku a Slovinsku). Zaměřili jsme se na následující klíčové aspekty: a) hlavní charakteristiky biologie jako školního předmětu (respektive biologické části předmětu „přírodní vědy“); b) specifika a uspořádání vzdělávacího obsahu; c) pojetí biologie jako vědní disciplíny; d) didaktická doporučení a požadavky; e) pojetí jednotlivých klíčových biologických disciplín; f) další kritéria, jako např́iklad důraz na lokální aspekty nebo občanskou angažovanost.

Za velmi inspirativní považujeme vzdělávací programy Estonska a Slovinska, ve kterých jsou obecné vzdělávací cíle velmi dobře rozpracované na úroveň konkrétního vzdělávacího obsahu a požadovaných standardů znalostí. Pro jednotlivá témata poskytují náměty na praktickou činnost žáků a využití ICT ve výuce. Slovinské kurikulum uplatňuje ve výuce biologických témat holistický přístup. Estonské kurikulum poskytuje dobrý př́klad začlenění místních aspektı̊, jako jsou typické místní ekosystémy. Kurikula obou těchto států zdůrazňují, že biologické znalosti a př́rodovědná gramotnost mají zásadní význam pro život jednotlivce i společnosti.
\end{abstract}

Klíčová slova: biologie, kurikulum, kurikulární reforma, 2. stupeň základní školy, př́írodní vědy. 
In the Czech Republic, a revision of national curricular documents for primary and secondary education, the Framework Educational Programmes, is being prepared and intensively discussed. Our aim is therefore to contribute to the ongoing professional discussion and to select the key aspects of foreign curriculum documents that can be inspiring for the Czech Republic.

We compare the concept of the biological part of the science curricula for lower secondary education, the second stage of basic school (from the $6^{\text {th }}$ to the $9^{\text {th }}$ grades) in the Czech Republic and for corresponding school grades in five other European countries, namely Estonia, Hungary, Poland, Slovakia and Slovenia, and evaluate their strengths and weaknesses in the light of current pedagogical literature. These post-communist countries joined the European Union a few years after the millennium and subsequently performed their curricular reforms according to EU-legislation. Hungary, Poland and Slovakia were selected as our nearest post-communist neighbours, sharing a similar history after World War II. Estonia and Slovenia were added to our comparison, because they scored above the OECD average in PISA (OECD, 2016) and their curricula might thus provide a desired inspiration for our planned curricular reform. We were methodologically inspired by Pawilen and Sumida (2005), who compared the educational programmes of the Philippines and Japan. In our comparison, we focused on the major characteristics of the school subject biology, subject matter, biology as a scientific discipline, didactics of biology, and the ways of teaching biological disciplines.

\section{Theoretical Background}

There are numerous studies describing the decline of pupils' interest in science and science subjects both in the Czech Republic and abroad (Bílek, 2008; Dawson, 2000; Osborne, Simon \& Collins, 2003; White Wolf Consulting, 2009). The attitude toward science is declining as well (Abrahams, 2007; Haste, 2004). The most frequently mentioned reasons are that science subjects are not relevant and are isolated from pupils' everyday lives (Rennie, Goodrum \& Hackling, 2001) and therefore are perceived as difficult (Lyons, 2006; Shirazi, 2017) and boring (Ebenezer \& Zoller, 1993; Goodrum, Rennie \& Hackling, 2001). In contrast, some studies revealed that lessons in some science disciplines (especially biology) are relatively popular among pupils (Prokop, Prokop \& Tunnicliffe, 2007) and biological topics, such as human health, are more interesting for the pupils than technological science (da Silva et al., 2018). Also, the difficulty perceived by the pupils strongly differs between particular topics (Cimer, 2012).

Another problem is the huge amount of knowledge which is required, rather than problem solving, literacy and creativity (Hong, Shim \& Chang, 1998; Koul \& Fisher, 2002; Lindahl, 2003; Osborne \& Collins, 2001; Šorgo, 2012). Therefore, it is crucial to re-evaluate what and how to teach (Škoda \& Doulík, 2009; Vařejka, 2006). When looking for an answer to the question of how to teach, we can find some possible solutions in published research studies. Hands-on and minds-on teaching forms and methods have the potential to improve pupils' attitudes toward science (Šorgo \& Špernjak, 2009; Uitto \& Kärnä, 2014) and increase their motivation and interest (Grant, Malloy \& Hollowell, 2013; Holstermann, Grube \& Bögeholz, 2010; Janštová, 2017). The teaching content has to be relevant to the students (Hassan, 2011; Lindahl, 2003; Lindner, 2014). Pupils should have the opportunity to be active and discuss freely (Freeman et al., 2014; Lyons, 2006). Dealing with living 
organisms is advisable when learning biology (Randler, Hummel \& Prokop, 2012), as well as learning outdoors, e.g., during field trips (Žoldošová \& Prokop, 2006). Practical indoor courses can be also effective if taught properly (Stohr-Hunt, 1996; van den Berg, 2013). Inquiry is recognised as an advisable method as well as it includes scientific principles as described, e.g., by Papáček (2010) or Bogner and Sotiriou (2014). Although the abovementioned principles are widely accepted, the reality at Czech schools is often different. More and more teachers recognise the term "inquiry" or "inquiry-based science education", although Radvanová, Č́źžková and Martinková (2018) pointed out that the terms are quite often misunderstood by Czech teachers. This is in concordance with the fact revealed by PISA (OECD, 2016) that Czech pupils have only limited chances to carry out experiments and use inquiry at school. Science literacy has been tested on a regular basis by PISA. The latest results (2015 testing) show that pupils from Poland, Estonia and Slovenia scored above the OECD average and did not perform worse than in 2012. In contrast, pupils from the Czech Republic scored significantly worse in the 2015 testing compared to three and nine years before. In general, Czech pupils have better content knowledge than procedural knowledge (OECD, 2016).

Since the late 1990s until the school year 2006/2007, Czech schools had to choose between two alternative state educational programmes for the second stage of basic school (lower secondary education) - the more widespread "Základní škola" (MŠMT ČR, 2003) and the less common "Národní škola" (MŠMT ČR, 1997), with more or less fixed structuring of subject matter into particular study grades. Since the school year 2007/2008, the original educational programmes were replaced by the Framework Educational Programme for Basic Education, which has been gradually updated (MŠMT ČR, 2017). This principal curricular reform followed EU legislation, gave the schools more freedom in arrangement of teaching content and aimed to incorporate the abovementioned modern educational trends in the Czech school system.

Recent studies indicate that the curricular reform in Czech schools was adopted only formally, the teachers have not accepted it and therefore there is no great impact on everyday teaching (Dvořák, Starý \& Urbánek, 2015; Janík et al., 2010; Janík, 2013; Stech, 2013). The reason is probably underestimating the need for a broader discussion and agreement among teachers, teacher trainers and the professional public, together with missing methodology that would support the reform (Straková, 2013). Another problem was that the teachers were required to prepare themselves and their school for the reform after their ordinary teaching hours, virtually in their free time (Kuřina, 2014). Currently, a revision of the Czech Framework Education Programme (MŠMT ČR, 2017) is being prepared. This offers a great opportunity to search for inspiration in other studies focused on curricular documents or in the documents themselves.

Many studies focus on comparing science education in different countries. Most of them can be divided into the following five groups according to their predominant perspective:

a) Studies concentrating on how a particular topic is dealt with in countries with different national curricula (Erdoğan, Kostova \& Marcinkowski, 2009; Poupová, 2018; Zembylas, 2002);

b) Studies comparing different school educational programmes based on the same national curriculum (Hayes \& Deyhle, 2001);

c) Studies comparing textbooks (Park, Park \& Lee, 2009); 
d) Studies describing differences monitored directly during science lessons at schools (Su, Su \& Goldstein, 1994, 1995);

e) Studies comparing pupils' results in connection with the type of their school curriculum (Kim, Lavonen \& Ogawa, 2009; Russell \& Weaver, 2011; Schmidt et al., 1996);

f) Studies describing the development of curricula or comparing selected aspects of curricula of different school subjects in particular countries (Ayas, Çlepni \& Akdeni, 1993; Šorgo \& Špernjak, 2012).

In contrast, studies providing detailed and complex comparative analysis of the entire science/biology part of national curricula of several countries are rather scarce (Grajkowski, Ostrowska \& Poziomek, 2014; Pawilen \& Sumida, 2005). We believe this type of study is urgently needed and therefore we have chosen this approach for our study. Our results may provide important arguments and inspiration for the ongoing professional discussions about the new form of the Czech national curriculum.

\section{Methods}

The national curricular documents (educational programmes for basic schools) that were used in our study are stated in the References. We studied their latest available online editions. The Czech (MŠMT ČR, 2017), Slovakian (ŠPÚ, 2015), Slovenian (MIZS, 2011a, 2011b, 2011c; MIZS, 2014) and Polish (MNE, 2018) documents were studied in their original languages. The Estonian (Government of the Republic of Estonia, 2014a, 2014b) and Hungarian (The Government of Hungary, 2014) documents were studied in their official English translations.

We formulated the following categories for a qualitative content analysis. In the comparison, we used criteria stated in Appendix I. We focused on the following categories:

a) The major characteristics of biology as a school subject: These comprise, e.g., whether biology is taught as a separate subject or as a part of an integrated science subject, what its aims are and its prescribed time allocation (see nos. 2, 3, 4 and 9 in Appendix I.).

b) Subject matter: its specification, arrangement, etc. (see nos. 5, 6, 7, 8, 10 and 11 in Appendix I.).

c) Biology as a scientific discipline: its specifics, history, relationship to society and to other disciplines and adoption of scientific methodology (see nos. 15, 16, 18, 19, 21 and 25 in Appendix I.).

d) Didactic recommendations and requirements for biology lessons: These comprise the required equipment of classrooms, number of practical lessons, recommended teaching methods or forms of assessment (see nos. 20, 23, 24, 26 and 27 in Appendix I.).

e) Way of treating crucial biological disciplines: taxonomy, evolutionary biology, cell biology and ecology (see nos. 11, 12, 13, and 14 in Appendix I.)

f) Other criteria: such as emphasis on local regions or public engagement that did not appear in all documents (see nos. 17 and 22 in Appendix I.). 


\section{Results}

\subsection{Stage OF SCHOOL}

In this chapter, we compare biological parts of the intended national curricula in the Czech Republic (CZ), Estonia (EST), Hungary (HG), Poland (PL), Slovakia (SK) and Slovenia (SLO). We focus on lower secondary education, represented by the second stage of Czech basic schools ( $6^{\text {th }}$ to $9^{\text {th }}$ grades). This corresponds approximately to the Slovakian, Polish and Hungarian second stages $\left(5^{\text {th }}\right.$ to $9^{\text {th }}$ grades in Slovakia, $5^{\text {th }}$ to $8^{\text {th }}$ grades in Hungary, $4^{\text {th }}$ to $8^{\text {th }}$ grades in Poland), Estonian and Slovenian second $\left(4^{\text {th }}\right.$ to $6^{\text {th }}$ grades $)$ and third stages $\left(7^{\text {th }}\right.$ to $9^{\text {th }}$ grades $)$. In Slovenia, the second stage ( $4^{\text {th }}$ to $6^{\text {th }}$ grades) is considered as a part of primary education (see Šrgo \& Śpernjak, 2012), but we included it into our study for the sake of better context.

\subsection{INTEGRATED SCIENCE OR SEPARATE BIOLOGY}

In the above-mentioned stages of basic school, biology can be taught either as an independent subject or as a part of an integrated subject called "science". Biology as a separate subject is taught in Poland and Slovakia, Czech schools can decide which way they prefer (either biology or science). In Estonia, science is taught in lower grades (till $7^{\text {th }}$ grade) whereas biology is taught in higher grades (from $7^{\text {th }}$ grade on). Similarly, in Slovenia, science is taught in the $6^{\text {th }}$ and $7^{\text {th }}$ grades, with about two thirds of time allocation devoted to biological topics. Biology is taught as a separate subject in the $8^{\text {th }}$ and $9^{\text {th }}$ grades. Moreover, in Slovenia, pupils in the $8^{\text {th }}$ and $9^{\text {th }}$ grades can choose among a variety of optional subjects, including those focused on biological, environmental, agricultural and health related topics (MIZS, undated). Optional subjects (electives) are not included in our study. In Hungary, the integrated science subject for the whole second stage is planned.

\subsection{Prescribed time AlLOCATion}

In some countries the time allocation for biology or science is specified by the proper educational programme (see Appendix, row No. 4). It is stated either as the number of hours per week or per school year (CZ, EST, SK, SLO), or as the percentage of time $(\mathrm{HG})$ devoted to that particular educational subject. The time allocation can be either minimal (CZ, HG) or obligatory (EST, SLO). Only in Estonia and Slovenia is the time allocation prescribed for biology as a separate subject. The exact number of hours is not stated in the Polish document.

\subsection{OBJeCtives AND EXPECTED OUTCOMES}

All of the countries studied (CZ, EST, HG, PL, SK, SLO) have similar objectives for science (or biology) in basic schools. In accordance with the Estonian document we can divide these objectives into: a) scientific knowledge, b) inquiry skills and c) values and attitudes. All of the countries studied formulate key competences in a similar manner. These competences are usually common to all science subjects, thus not only to biology, but to physics, chemistry and geography as well, but in the Slovenian document for the $8^{\text {th }}$ and $9^{\text {th }}$ grades, the key competences are elaborated also specifically for biology. One of the main aims of the 
science subjects is to promote scientific literacy by gaining appropriate methodological competences: Pupils should formulate questions, observe natural phenomena, solve problems, do experiments, analyse data, draw conclusions from them, use different information sources and present their results. Pupils also should understand the relationship between nature and society, feel responsible for the environment and make competent decisions in everyday life. Pupils should also have positive attitudes to nature and value natural sciences. In the Slovenian documents, the demands on the pupils' inquiry skills are elaborated for each study grade and are gradually increasing from $6^{\text {th }}$ to $9^{\text {th }}$ grades and a positive attitude towards science is accented.

\subsection{Distribution OF SUBJECT MATTER INTO GRADES}

In some countries (PL, SK, SLO), the educational programme describes how to sketch out the subject matter into particular grades, but these recommendations need not be compulsory (PL). In other countries (CZ, EST, HG), the educational programme just states that the subject matter should be taught in the second stage (in EST either in the second or third) and schools themselves decide how to distribute the subject matter into the particular grades. In Hungary, the educational programme makes a difference between pairs of grades, $5^{\text {th }}$ and $6^{\text {th }}$ on one hand and $7^{\text {th }}$ and $8^{\text {th }}$ on the other, and describes the subject content for each of these pairs.

\subsection{Structuring of SubJeCt Matter}

In some countries (CZ, HG, PL) where the schools themselves decide what to teach in which grade, the subject matter in the educational programme is structured into biological disciplines (botany, zoology, human biology, genetics, ecology, etc.). The situation is different when the order of topics is obligatory (SK, SLO) and it is even more complicated in Estonia where the educational programme determines the stage $\left(2^{\text {nd }}\right.$ or $3^{\text {rd }}$ ) and also the type of subject (science or biology). Both Slovakia and Estonia start with an ecological view of nature (in $5^{\text {th }}$ and $6^{\text {th }}$ grades in SK, and in $2^{\text {nd }}$ stage science in EST) and focus on life in various ecosystems or near human settlements. In higher grades, the attention moves to various groups of organisms (plants, mushrooms, microorganisms, invertebrates, vertebrates), human biology, genetics, ecology and environmental protection. The Slovenian documents apply a holistic approach to biological teaching content. They clearly follow three hierarchical levels - cell, organism and ecosystem, which are continuously present from the $6^{\text {th }}$ to the $9^{\text {th }}$ grades and also the links between them are clearly defined (MISZ, 2011a: scheme on p. 30). The Slovenian $6^{\text {th }}$ grade focuses mainly on the biology of plants; $7^{\text {th }}$ grade on the biology of bacteria, fungi, animals and ecosystems; $8^{\text {th }}$ grade on cell biology and human biology. The Slovenian $9^{\text {th }}$ grade is devoted to more general, synthesizing and applied topics, such as evolution, genetics, biotechnologies, biodiversity, and biology and human society.

\subsection{DePth OF LEARNING CONTENT}

The learning content in the majority of the countries studied (CZ, HG, PL, SK) is not specified in detail. It is described briefly, and only in outline records the structure of that particular topic. It cannot be understood as a list of terms and 
theories pupils should learn. The Estonian and Slovenian documents distinguish between biological concepts and learning content. Formulations such as "pupils give examples" or "determine the most important species" are used without explicit specification of those examples and species. In zoology, the following taxa are mentioned: cnidarians, coelenterates, molluscs, arthropods, worms, fish, amphibians, reptiles, birds and mammals. In botany, the Czech and Slovenian educational programmes are the most detailed - they mention algae, mosses, sporogenous plants, conifers, monocotyledonous and dicotyledonous angiosperms, which the other countries do not specify. In human biology, the compared educational programmes state the same topics ordered in the same way (bones and muscles, circulatory, respiratory, digestive and excretory tract, nervous system, reproduction and ontogenesis of man). The Slovenian document puts a strong emphasis on the pupils' understanding of the relation between the anatomy of organs, their physiological function and human health (e.g., "pupils understand the connection between the structure and the function of the eye (the appearance of the image), they correlate this with errors and corrections of vision, risks of injury, prevention and first aid,"; MIZS, 2011a: p. 12, paragraph D8-2).

\subsection{INCORPORATION OF GEOLOGY}

All of the countries include at least some geological topics in the subjects science or biology. In some of them (CZ, SK), the whole of geology is covered by the topic "Inanimate nature", and "The history of Earth", while in the others just certain topics are included (EST, SLO). Geology can also be part of geography (PL, SLO, in CZ it can be so as well, depending on the particular school's educational programme). In Hungary, geology is incorporated especially in two subject areas - "The earth - our environment" and "Man and nature" encompassing science, biology, geography, chemistry and environmental science in general. In Slovenia, geological content is briefly covered by the teaching content "Rocks and soil" in the $6^{\text {th }}$ grade.

\subsection{EdUCATIONAL AND PRACTICAL AIMS}

The expected outcomes are many practical skills that can be used in everyday life. In all of the countries studied, they are connected with human biology and a healthy lifestyle. We can give the following examples of expected outcomes: giving first aid, behaving safely in nature, following hygienic rules and rules preventing one from diseases, behaving in an environmentally-friendly manner, maintaining a healthy lifestyle (healthy eating habits, avoiding drug abuse), behaving in a sensible way during ecological disasters and behaving in a sexually responsible way. Topics connected with agriculture and food processing are also valuable from a practical point of view. For example, the Slovakian document states such topics as types of vegetable, fish farming and beekeeping. Slovakian and also Czech pupils should, among others, learn how to differentiate between poisonous and edible mushrooms. Estonian pupils should be able to make compost. The Hungarian document states several times that pupils should gain a critical approach to pseudoscientific, antiscientific and anti-technological assertions. In Hungary, Estonia and Slovenia, the ability to operate with new technologies and ICT is accented. 


\subsection{OPPORTUNITY FOR PUPILS AND TEACHERS TO INFLUENCE WHAT IS TAUGHT}

In Estonia, there is a passing reference that it is important to plan investigationbased assignments that follow the pupils' interests and experiences. In Slovenia, teachers are allowed to use up to $20 \%$ of the overall time allocation for biology in the $8^{\text {th }}$ and $9^{\text {th }}$ grades for more detailed teaching of topics according to the pupils' abilities and interests, current issues and/or the local situation. In the other countries, the opportunity for pupils to influence what they learn is not mentioned at all.

\subsection{TAXONOMIC DEMANDS}

Classification of organisms is a relatively marginal part of the biology curricula in the countries studied. Their expected outcomes usually state that pupils should classify organisms into appropriate taxa (on the level of main classes of vertebrates and phyla of invertebrates and plants). Moreover, the Czech Republic, Hungary, Poland and Slovenia require knowledge of taxonomic principles. Slovenian pupils of the $9^{\text {th }}$ grade shall understand basic principles of phylogenetic systematics. A list of definite species of organisms that pupils should learn about is not stated in any country. Especially in Estonia, Slovenia and Slovakia, botany and zoology are not treated in a systematic manner, but rather a comparison of the physiology (reproduction, etc.) of various groups of organisms is required.

\subsection{INCORPORATION OF EVOLUTION}

In some countries (EST, PL, SLO), evolution is set as a separate chapter. Estonian and Polish documents state a few expected outcomes connected with evolution such as explaining principles of biological evolution, comparing humans and other vertebrates, etc. In Slovenia, "Evolution" is one of the crucial themes of the $9^{\text {th }}$ grade and is recognised as a central one. The chapter is relatively comprehensive, with 18 well elaborated expected outcomes which put rather high demands on the cognitive abilities of pupils and a fundamental knowledge of genetics (e.g., "pupils recognize that evolution is a gradual process in which the new complex properties of an organism arise through many generations; mutations are random in the sense that they are not aimed at improving the organism; natural selection is not accidental", MIZS, 2011a: p: 17, paragraph J1-5). In the Czech Republic, evolution is included in three different chapters: Introduction to biology, Phylogenesis of man, and Inanimate nature. In Slovakia, it is a short part of the chapter History of the Earth and human evolution is not mentioned at all. However, in Slovakia, evolution is also a part of other topics, such as biocenosis (in the 5th grade), diversity of vertebrates (in the $7^{\text {th }}$ grade) and ecological factors (in the $9^{\text {th }}$ grade). The Hungarian document speaks about evolution in various places in the subject area "Man and nature", especially in the biology subject. This section contains several references to the evolution, e.g., regarding the topic of History of science and Constancy and Diversity of the living world. Except for Hungary, evolutionary principles are not involved in other topics. In the Hungarian document an evolutionary approach is, among others, used in geography for analysing the geographical distribution of plant and animal species. 


\subsection{TREATING ECOLOGY}

Lower grades in some countries (EST, HG, SK) present an ecological view of nature. This is especially true for Estonian second stage science. Organisms and their life processes are dealt with in connection with their environment (wild animals and their ecosystems or domestic animals and organisms living in human settlements). The Estonian document focuses a great deal on Estonian and Baltic wildlife. In higher grades in Estonia and Slovakia, environmental protection and ecology is incorporated as a separate discipline. In the Czech Republic and Poland, ecology and environmental protection are dealt with as separate chapters but we must be aware of the fact that the schools do not have to follow strictly the structuring of the learning content stated in educational programmes. In Slovenia, ecological topics start in the $6^{\text {th }}$ grade with the roles of plants in ecosystems; continue with the ecological roles of animals, bacteria and fungi and with the structure and functioning of ecosystems, and ends in the $9^{\text {th }}$ grade with biomes, the biosphere and biodiversity.

\subsection{TREATing CELL BiOLOGY}

In some countries (EST, SK), cell biology is not described as a separated chapter and specific characteristics of bacterial, plant and animal cells are mentioned when the group of organisms is being discussed. Details about the nucleus are incorporated into genetics. The structure of the cell is taught before the cell functioning. In other countries (CZ, PL), cell biology is a part of the introduction to biology. (But as has been stated above, the Czech document does not demand the following of the prescribed order of topics.). In Hungary, some information about cells are in a separate topic (Life processes at the cell level, Types of plant and animal tissues), and other information is mentioned elsewhere. The Slovenian curriculum, in contrast, puts a strong emphasis on cell biology from the $6^{\text {th }}$ up to the $9^{\text {th }}$ grades - starting with plant cells, continuing with animal, bacterial and fungal cells and graduating with general topics such as cell physiology and genetics.

\subsection{INCORPORATION OF HISTORY OF SCIENCE}

The history of science seems to be a relatively marginal part of the studied curricula as it is not systematically incorporated in any of them. Marginal remarks that appear in the Hungarian, Czech and Slovenian documents follow: Hungarian pupils should be occupied with the history of science to get to know the nature of science. They should, for example, describe the evolution of models and theories or analyse the advantages and limitations of methods of obtaining knowledge. In the Czech educational programme, there is one reference of peripheral importance about the historical development of biology (or science). Slovenian teachers should present biological facts as the result of the work of many scientists throughout centuries of research. Their pupils should recognise the significance of biological discoveries (e.g., Darwin's Theory of Evolution or the structure of DNA). In EST, PL and SK hardly any remarks about the history of science can be found.

\subsection{RELATIONSHIP BETWEEN SCIENCE AND SOCIETY}

As far as the relationship between biology and society is concerned, educational programmes in the countries studied concentrate on utilisation (growing plants and 
breeding animals, forestry), environmental protection (responsibility for the environment, sustainability), medicine and the merits and risks connected with various technologies. Pupils are expected to understand the connections between human activities and the environment as well as between various scientific disciplines; they should also express respect for living beings. Moreover, in Hungary, avoidance of pseudoscientific approaches is mentioned.

\subsection{EMPHASIS ON LOCAL REGIONS}

Preferring topics connected with local regions is especially striking in the Estonian educational programme. Estonian pupils should (especially in the second stage) occupy themselves with environmental problems near their home and focus on wildlife in their homeland or in the Baltic Sea. In the other countries (HG, PL, SK, SLO) the emphasis is not so striking, nonetheless, pupils should also determine common species living near their school, find information about the local region and do experiments (or observations) near their home. Slovenian pupils should understand the reasons for the high biodiversity found in Slovenian nature. Only in the Czech Republic are local regions not accented.

\subsection{INTERDISCIPLINARY LINKS AND THEIR FULFILMENT}

In the introductory part of the educational programmes, the need to promote interdisciplinary links is stated. This is so in all of the countries studied. These links are stated in general without any particular recommendation on how to do so. In Estonia and Slovenia, connections between biology and general competences (cultural and values, social and citizenship, self-awareness, communication, mathematics and entrepreneurial competence) are more elaborated. These pieces of advice are short but usable in practice (e.g., the demand for oral presentations on results from observations to bolster the pupils' communication competence).

\subsection{RELATED EDUCATIONAL AREAS AND CROSS-CURRICULUM SUBJECTS}

Biological topics are also incorporated in other educational areas and cross-curriculum subjects. In CZ, these are the educational areas Man and health, Man and work (plant growing and breeding, laboratory technique), the cross-curriculum subject Environmental education and the optional educational field Ethical education. In Slovakia, the relevant educational areas are Man and work (plant growing and breeding), Health and movement, the cross-curriculum subject Environmental education, Health and life protection and Sexual education. In Estonia, many biological problems are dealt with in the educational areas Environment and sustainable development and Health and safety, in Hungary, there is an educational area called Way of life and practical skills. Similar trends can be seen in the Slovenian curriculum, especially in the $6^{\text {th }}$ and $7^{\text {th }}$ grades, where the integrated science subject is taught. No related educational areas are mentioned in Poland.

\subsection{RECOMMENDED TEACHING METHODS}

Estonia and Slovenia pay the most attention to teaching methods from all of the countries studied. In Estonia, various teaching methods and activities should be 
used, including homework, pair and group work, extending the study to museums and school surroundings (outdoor learning), role play, discussions, project work, creating a study folder and a research paper, and practical and research related work. In the Slovenian document, didactic recommendations are included as are well elaborated separate chapters, but the teachers are autonomous in choosing from among the methods. In addition to particular teaching methods, they include also general topics, such as remedying the pupils' misconceptions or promoting their interest in biology. In the other countries, less attention is paid to this topic, it is often said that the methods should be varied (HG, PL) and that inquiry-based learning and the pupils' own activity should be preferred (CZ, SK). In the Slovakian document, creating mental maps is mentioned several times. The Polish document strongly recommends using various types of information (pictures, films, texts, animations, internet data, etc.), outdoor learning and field work (examples of suitable experiments are stated in Polish syllabi).

\subsection{SPECIFIC BIOLOGICAL SKILLS}

Scientific skills pupils should gain during biology lessons are the following: species identification with the help of identification manuals (HG, CZ, SK), designing experiments and observing animal behaviour (CZ, PL, SK), and using a microscope or magnifying glass for observation (CZ, HG, PL, SK, SLO). In Slovakia and Slovenia, the inquiry skills are interconnected with presentation and communication skills. The Estonian, Hungarian, Polish and Slovenian documents speak more generally about solving scientific problems (choosing appropriate methods, creating models, collecting information, formulating hypotheses, recording data, drawing conclusions and presenting summaries). In Estonia, particular biological skills are incorporated into practical tasks (see below).

\subsection{Public Engagement}

In Slovakia, we can find the requirement that pupils should become involved in raising public awareness of natural scientific issues. The motivation to participate in age-appropriate environmental protection events or activities supporting public health is demanded. To a certain degree, we can find this demand in Estonia and Slovenia, as well; the other countries do not refer to it. Polish pupils should show and share their opinions on current biological topics such as genetic modification, and ecological and nature conservation issues.

\subsection{REQUIRED PRACTICAL LESSONS}

In the educational programmes, practical work in a laboratory and field research are mentioned as essential teaching methods. In Hungary, the minimum number of practical lessons is set down. (In the $5^{\text {th }}$ grade, pupils should perform at least two independent experiments per year, present their notes or drawings at least four times per year and prepare one work on a science-related subject. In the $7^{\text {th }}$ and $8^{\text {th }}$ grades they should perform at least two biological experiments or examinations per year and take part in at least one practical activity outside the school.) The Slovenian curriculum for science requires that at least $40 \%$ of teaching hours in the $6^{\text {th }}$ and $7^{\text {th }}$ grades be based methods of work, with an emphasis on classroom and field experimental research. In the $8^{\text {th }}$ grade at least 10 and in the $9^{\text {th }}$ grade at 
least 13 teaching hours of biology (at least $20 \%$ of the total time allocation) must be devoted to experimental and fieldwork in smaller groups. In Estonia, tasks for practical work are listed for every topic. (This is called "Practical work and use of ICT" and is comprised of usually 3 to 5 tasks that may involve field research and other activities outside of school: e.g., studying the sprouting of seeds in different environmental conditions, making a model of an organ, going for a study trip to a nature reserve, etc.) The minimum requirement of outdoor learning is also stated in the Estonian document. (In the second stage of study, pupils should visit an environmental centre, museum or laboratory outside of the school at least twice, in the third stage of study in every science subject once during the academic year.) Practical tasks in the other countries (CZ, HG, PL, SK, SLO) are not specified so precisely. They are embodied in expected outcomes: Pupils should, for example, monitor pollution in the school's surroundings (SK) or do an experiment with yeast fermentation (PL). More detailed examples can also be included in the supporting document $(\mathrm{PL})$.

\subsection{REQUIREMENT OF METHODOLOGICAL SKILLS}

All of the countries' demands on methodological (inquiry) skills are high. As has been written above, pupils should be able to solve scientific problems using appropriate methods (observation, experiment), they should be able to plan their research, formulate hypotheses, collect the information needed, analyse data and draw conclusions from the data. These inquiry skills are described in the general characteristics of scientific education and are embodied in expected outcomes (CZ, HG, PL, SK, SLO), while in Estonia they are addressed also in connection with particular learning content.

\subsection{EQUIPMENT OF LABORATORIES AND SPECIAL CLASSROOMS}

The equipment needed for laboratory and practical work is also discussed in educational programmes (except for HG). Estonia and Poland explicitly state very concrete demands (classrooms with hot and cold water, sinks, sockets, working desks, microscopes, binoculars, different sensors per class, first aid kit, models of human organs, sets of microscopic sections or technology for a teacher's demonstration). Other countries (CZ, SK, SLO) just state that schools should have special classrooms with appropriate equipment.

\subsection{Specification of ASSESsment}

There is nothing said about pupils' assessment in the Czech Republic, Hungary, Poland and Slovakia. In contrast, Estonia pays much attention to this issue. It is stated that teachers should use oral assessment and/or numerical grades and that the assessment should be applied to attitudes and pupils' behaviour, too. Estonian teachers should correct grammar mistakes in written assignments (but not take them into account in the assessment), pupils must know the criteria for assessment, and their inquiry skills and active participation in discussions must also be evaluated. In the third stage of study, thinking in the context of the subject should be $80 \%$ of the grade ( $40 \%$ being tasks that require the use of lower levels of thinking, $40 \%$ being tasks that require the use of higher levels of thinking) and development of research and decision-making skills should make up the other $20 \%$ of the grade. 
Slovenia has a well elaborated way of general assessment of pupils' achievement of the expected standards of knowledge. Three standards of knowledge are distinguished; standard 1 defines the minimum, and standard 3 is the most advanced knowledge. The Slovenian standards are not based on details of the learning content, but on understanding the principles, ability to use the knowledge in a broader context, proper interpretation of facts and taking a stance on the issue based on relevant arguments.

\section{Discussion}

\subsection{General Features of the StUdied CURricula}

From the detailed comparative analysis presented above, we can infer the following general characteristics of the biological parts of the six national curricula studied:

The Estonian and Slovenian educational programmes are precise and the general aims are very well elaborated on the level of the particular learning content. In comparison with the other countries they specify practical work and assessment of pupils' performance and outcomes in the most sophisticated way. They also state particular recommendations on how to fulfil its demands (e.g., how to deepen interdisciplinary bonds or which teaching methods to choose). Moreover, the Estonian and Polish educational programmes specify also the required classroom equipment. There is a heavy emphasis on using ICT in Estonia and Slovenia. In Estonia, the education is (especially in the lower grades) centred on the local region and applies an ecologically-oriented approach. This is facilitated by the existence of an integrated subject, science.

The educational programmes of the Czech Republic, Slovakia and Poland are much alike. There is huge freedom for schools: Czech schools can even choose whether to teach biology or science, and Czech and Polish schools can decide on their own what to teach in which grade. None of these countries specify the learning content in much detail. Slovakia differs from the other two countries in the respect that it applies an ecologically-oriented approach in lower grades and that it emphasises the need of the pupils' participation in public educational and environmental activities.

The Hungarian educational programme prefers an ecologically-oriented and interdisciplinary approach. This document is the least detailed; it states a great many general proclamations and lets the schools arrange the education at their own discretion.

\subsection{Do THE NATIONAL CURRICULA FOSTER PUPILS' INTEREST IN BIOLOGY?}

In agreement with published studies which point out the need of connecting biology and science education to everyday life in order to make it relevant (Hassan, 2011; Lindahl, 2003; Rennie, Goodrum \& Hackling, 2001), all of the analysed curricula mention topics which are useful and needed in everyday life. These are mainly human health, poisonous plants, domestic animals, environmental protection and, very importantly, avoidance of pseudoscientific approaches (HU). Most of these topics are cross-curriculum subjects. The issue of connecting scientific issues and everyday life 
is raised in several curricula (EST, PL, SK, SLO). Another part of the content being relevant is learning about local regions, which is a very important part of the Estonian curriculum and is also mentioned in other national curricula (HG, PL, SK, SLO) but not in the Czech Republic. Learning about local regions can naturally happen outdoors as many studies recommend (e.g., Žoldošová \& Prokop, 2006). Outdoor learning has to be used in Estonia, Poland and Slovenia according to their curricula. Another essential recommendation from literature is to let the pupils find their own way of solving problems, doing inquires and discussing (Freeman et al., 2014; Lyons, 2006; Šorgo \& Špernjak, 2009; Papáček, 2010). This is also reflected by the analysed curricula, as in all of the countries studied inquiry or solving scientific problems should be used while teaching biology. Quite naturally, pupils are required to present and communicate their thoughts by some curricula (EST, HU, PL, SLO). Discussion is pointed out in the Estonian curriculum, which is the most detailed among the studied curricula where talking about teaching methods is concerned. Practical courses are also ordered by all of the compared curricula, with the Estonian one being the most detailed and including "Practical work and use of ICT" in every topic and the Slovenian one which requires a high proportion of laboratory and field practical work in small groups. Interestingly, even more importance to practical work compared to biology is given in the chemistry and physics parts of the Slovenian curriculum (Šorgo \& Špernjak, 2012). As literature suggests, a hands-on, together with a minds-on approach, is effective (Stohr-Hunt, 1996; van den Berg, 2013). Among other topics, observing animal behaviour is also mentioned in some curricula (CZ, PL, SK), as recommended by Fančovičová and Prokop (2017), Prokop and Fančovičová (2017) and Randler, Hummel and Prokop (2012). In spite of the emphasis on practical activities in the Slovenian curricula, Sorgo (2012) pointed out that little attention is placed on the development of the pupils' creativity.

Regarding structuring the subject matter, an interesting pattern was revealed. While some countries (CZ, HG, PL), where the decision on what to teach in which grade is left up to schools, have the subject matter in the educational programme structured into biological disciplines (botany, zoology, human biology, genetics, ecology, etc.), another situation was found in Estonia and Slovakia. These countries start with ecology (learning about ecosystems and focusing on various groups of organisms later) and continue with human biology, genetics, ecology and environmental protection. The order or even location in a grade is given. A similar case is the Slovenian curriculum, in which the distribution of subject matter within the grades is obligatory and the curriculum is constructed in a holistic way - each of the main groups of organisms are treated on the level of cell, organism (mainly anatomy and function) and ecosystem, with special emphasis on the links between the levels. $8^{\text {th }}$ grade is devoted to human biology and $9^{\text {th }}$ grade to general, synthetic and applied topics (e.g., biological molecules, evolution, human genetics, biotechnologies and environmental problems). This raises an interesting question of whether this pattern can be generalised and why it works better to give more structure to the subject matter in case of an "ecological and evolutionary" approach. One would expect links and interconnection within the subject matter to be crucial in any case, even when structuring biology into disciplines like botany, zoology, etc. Analysing more curricula is needed to answer this question. Structuring the subject matter in a different way does not seem to have a direct influence on science literacy as pupils from both Poland on one side and Estonia and Slovenia on the other scored above the OECD average in 2015 (OECD, 2016). 
There are several recommendations from the literature and analysed curricula which can be taken into account for the revision of the Czech curriculum. The main ones are to emphasise outdoor education, links to local place and community, and in general to mention more specific examples such as suitable practical courses, links to ICT, and the connections between biology and general competences. Although the Czech curriculum states experiments and inquiry should be used while teaching biology, PISA results from 2015 indicates that this, in reality, happens quite rarely (OECD, 2016). As experience from the last Czech curricular reform has shown, previous discussion with in-service teachers, teacher trainers and others involved in the educational process and acceptance by the professional public is essential (Straková, 2013).

The results of our study can be related to those stated in a Polish study by Grajkowski, Ostrowska and Poziomek (2014). This study compares core curricula for science subjects in Poland, England, Finland, Estonia, France, and in the Czech Republic. Thus, three of these countries are the same as in our study. The Polish paper lists several points that its authors find missing or insufficiently emphasised in the Polish core curriculum in comparison with the other countries. They use this list to suggest advice on how to improve the Polish educational programme. In the following passage we discuss their points and recommendations with respect to our study (Grajkowski, Ostrowska \& Poziomek, 2014: pp. 33-34, 37-38).

The Polish paper recommends combining science subjects, and stresses the need for stronger interdisciplinary links and a cross-curricular nature for Polish education. Having an integrated subject at least in the lower grades is supposed to be a contemporary trend. From our study we can infer that this is true especially in Estonia and Slovenia. Some authors (for example, Folta, 1998) recommend teaching the history of science to help create cross-curricular connections and overcome the traditional specialisation of scientific disciplines. However, as was shown in our study, none of the countries pay enough attention to this topic. The Polish study came to a similar conclusion, with the exception of England, where a tradition of teaching the history of science exists.

As the Polish study states, the need for an interdisciplinary approach is interconnected with problem-based coverage of teaching content. They suppose that a problem-based approach is more adequate for the $21^{\text {st }}$ century than teaching separate topics resulting from the $19^{\text {th }}$ century arrangement of natural sciences. According to our results, especially Estonia employs this approach. Moreover, both our study and the Polish study highlight the emphasis Estonia put on the application of ICT in various topics.

According to Grajkowski, Ostrowska and Poziomek (2014), the creation of a catalogue of skills common for all science subjects is needed. They mention especially those skills that are connected with scientific reasoning and scientific method (experiments and observations). They think such a list could enable moving the emphasis from teaching content to educational aims. Some authors state (e.g., Matthews, 2011) that doing science (or imitating it during school lessons) is one way to come to understand the scientific way of thinking. Learning about science and its nature is at least as important as learning science (Matthews, 2011). According to our study, scientific skills in the chosen countries are described only in general and having such a catalogue of skills could make deciding what to do during practical lessons easier.

The Polish study advises adding a few sections of content. They list ethical and moral issues related to science and the history of science. According to our study ethical and moral issues are partially present in the Slovakian document where the 
need for public engagement of pupils (their participation in the formation of public consciousness of scientific issues) is mentioned several times. Although Grajkowski, Ostrowska and Poziomek (2014) do not state any argument for teaching the history of science, there are many: History of science is supposed to show the way that scientific knowledge is formed and the nature of science as such. It presents science as a never-ending search for answers and prevents people from regarding today's state of scientific knowledge as an indisputable absolute truth (Horner \& Rubba, 1978). Moreover, according to some authors (e.g., Karpenko, 1997), the history of science can serve as a source of ethically interesting situations, thus, teaching the history of science can fulfil this need as well.

The Polish study also states that more attention should be paid to developing pupils' motivation to study science. They demand more concrete suggestions for how to make a pupil interested in science and affect his or her attitude towards the natural world (Grajkowski, Ostrowska \& Poziomek, 2014). Forming a positive attitude to science and nature is an educational aim of all curricula in all of countries we studied. To fulfil this requirement, concrete advice would be helpful.

\subsection{LimitaTiON OF OUR STUDY}

We are obligated to mention that although we explored the national curricula of all of the countries thoroughly and performed in-depth comparisons, it is not possible for our results to give a full picture regarding the educational processes in the selected countries. Moreover, in our study, we did not include an important link between the official national curricula and school reality - the textbooks. As we stated above, the evidence evinces that the reality often differs from the instructions of the national curricula. We also did not take into account issues overlapping into the humanities. Further, as we are not native speakers/citizens of all of the chosen countries (only of the Czech Republic), there is a possibility that we misunderstood some of the information and involuntary misinterpreted them. We tried, however, to reduce this to a minimum.

\section{Conclusions}

From the analysed curricula, the most inspiring were the Estonian and Slovenian ones, because they precisely elaborate general educational objectives into the level of the particular learning content and standards of knowledge. Moreover, the Slovenian document offers an inspiring holistic approach to the teaching of biological issues. The Estonian curriculum is a good example of incorporating local aspects, such as typical local ecosystems. We also find the content-specific links to practical work and ICT and the connections between biology and general competences in the Estonian curriculum very useful when using the documents in school practice. The national curricula of both countries recognise biological knowledge and scientific literacy as being very important for the individual and society.

This can be a good inspiration for revision of the Czech Framework Education Programme. Regarding this revision, both experience and literature show that public discussion and elaborate support for teachers are essential conditions for successful change. 


\section{ACKNOWLEDGEMENT}

This research was financially supported by the Charles University project UNCE/ HUM/024 "Centrum didaktického výzkumu v přírodních vědách, matematice a jejich mezioborových souvislostech". We are grateful to Dr. Eva Stratilová Urválková and doc. Svatava Janoušková (Charles University, Faculty of Science, Dept. of Teaching and Didactics of Chemistry) for their help in obtaining and translating the educational programmes of the compared countries and to the two anonymous referees for their constructive criticism and valuable comments on the manuscript.

\section{REFERENCES}

Abrahams, I. (2007). An unrealistic image of science. School Science Review, 88(324), $119-122$.

Ayas, A., Çlepni, S. \& Akdeniz, A. R. (1993). Development of the Turkish secondary science curriculum. Science Education, 77(4), 433-440.

Bílek, M. (2008). Zájem žáků o přírodní vědy jako předmět výzkumných studií a problémy aplikace jejich výsledků v pedagogické praxi. Acta Didactica, 2008(2), 1-15.

Bogner, F. X. \& Sotiriou, S. (2014). Pathway towards a standard-based approach to teaching science by inquiry. In C. P. Constantinou, N. Papadouris \& A. Hadjigeorgiou (Eds.), E-Book Proceedings of the ESERA 2013 Conference: Science education research for evidence-based teaching and coherence in learning (2579-2585). Nicosia, Cyprus: European Science Education Research Association.

Cimer, A. (2012). What makes biology learning difficult and effective: Students' views. Educational Research and Reviews, 7(3), 61-71. https://doi.org/10.5897/ERR11.205

Dawson, C. (2000). Upper primary boys' and girls' interests in science: have they changed since 1980? International Journal of Science Education, 22(6), 557-570. https://doi.org/10.1080/095006900289660

Dvořák, D., Starý, K. \& Urbánek, P. (2015). Malá škola po pěti letech: proměny školy v době reformy. Pedagogická orientace, 25(1), 9-31.

https://doi.org/10.5817/PedOr2015-1-9

Ebenezer, J. V. \& Zoller, U. (1993). Grade 10 students' perceptions of and attitudes toward science teaching and school science. Journal of Research in Science Teaching, 30(2), 175-186. https://doi.org/10.1002/tea.3660300205

Erdoğan, M., Kostova, Z. \& Marcinkowski, T. (2009). Components of environmental literacy in elementary science education curriculum in Bulgaria and Turkey. Eurasia Journal of Mathematics, Science \& Technology Education, 5(1), 15-26.

https://doi.org/10.12973/ejmste/75253

Fančovičová, J. \& Prokop, P. (2017). Effects of hands-on activities on conservation, disgust and knowledge of woodlice. Eurasia Journal of Mathematics, Science and Technology Education, 14(3), 721-729. https://doi.org/10.12973/ejmste/80817

Folta, J. (1998) Dějiny vědy a techniky 5. 15. a 16. seminář pro vyučující dějinám věd a techniky. In J. Folta (Ed.), Rozpravy NTM 157 (69-74). Praha: NTM.

Freeman, S., Eddy, S. L., McDonough, M., Smith, M. K., Okoroafor, N., Jordt, H. \& Wenderoth, M.P. (2014). Active learning increases student performance in science, 
engineering, and mathematics. Proceedings of the National Academy of Sciences, 111(23), 8410-8415. https://doi.org/10.1073/pnas.1319030111

Goodrum, D., Rennie, L. J. \& Hackling, M. W. (2001). The status and quality of teaching and learning of science in Australian schools: A research report. Canberra: Department of Education, Training and Youth Affairs.

Government of the Republic of Estonia. (2014a). Appendix 4 of regulation no 2 of the government of the republic of 6 January 2011. National curriculum for upper secondary schools (last amendment 29 August 2014). Subject Field: Natural Science. Tallinn.

Available at https://www.hm.ee/sites/default/files/

est_upper_secondary_nat_cur_2014_appendix_4_final.pdf

Government of the Republic of Estonia. (2014b). National curriculum for basic schools regulation (last amendment 29 August 2014). Tallinn. Available at

https://www.hm.ee/sites/default/files/est_basic_school_nat_cur_2014_general_part_1.pdf

Grajkowski, W., Ostrowska, B. \& Poziomek, U. (2014). Core curriculum for science subjects in selected countries - study report. Warsaw: Educational Research Institute.

Grant, D. M., Malloy, A. D. \& Hollowell, G. P. (2013). Enhancing students' interest in science and technology through cross-disciplinary collaboration and active learning techniques. Journal of Information Technology Education: Innovations in Practice, 12, 101-112. https://doi.org/10.28945/1782

Hassan, G. (2011). Students' views of science: A comparison between tertiary and secondary school students. Science Educator, 20(2), 54-61.

Haste, H. (2004). Science in my future: A study of values and beliefs in relation to science and technology amongst 11-21 year olds. London: Nestle Social research Programme. Available at http://opus.bath.ac.uk/22269/

Hayes, M. T. \& Deyhle, D. (2001). Constructing difference: A comparative study of elementary science curriculum differentiation. Science Education, 85(3), 239-262. https://doi.org/10.1002/sce.1008

Holstermann, N., Grube, D. \& Bögeholz, S. (2010). Hands-on activities and their influence on students' interest. Research in Science Education, 40(5), 743-757. https://doi.org/10.1007/s11165-009-9142-0

Hong, J.-L., Shim, K.-C. \& Chang, N.-K. (1998). A study of Korean middle school students' interests in biology and their implications for biology education. International Journal of Science Education, 20(8), 989-999.

https://doi.org/10.1080/0950069980200806

Horner, J. K. \& Rubba, P. (1978). The myth of the absolute truth. The Science Teacher, 45(1), 29-30.

Janík, T. (2013). Od reformy kurikula k produktivní kultuře vyučování a učení. Pedagogická orientace, 23(5), 634-663. https://doi.org/10.5817/PedOr2013-5-634

Janík, T., Janko, T., Knecht, P., Kubiatko, M., Najvar, P., Pavlas, T. \& Vlčková, K. (2010). Kurikulární reforma na gymnáziích - výsledky dotazníkového šetrení. Praha: Výzkumný ústav pedagogický v Praze. Available at http://www.nuv.cz/file/170

Janštová, V. (2017). Invertebrate dissections can motivate pupils toward studying biology. In M. Rusek, D. Stárková \& I. B. Metelková (Eds.), Project-based Education in Science Education XIV. (25-32). Prague: Charles University, Faculty of Education.

Karpenko, V. (1997). Výuka dějin chemie na vysokých školách. In J. Folta (Ed.), Dějiny vědy a techniky 3. Rozpravy NTM, 145 (121-125). Praha: NTM. 
Kim, M., Lavonen, J. \& Ogawa, M. (2009). Experts' opinions on the high achievement of scientific literacy in PISA 2003: A comparative study in Finland and Korea. Eurasia Journal of Mathematics, Science \& Technology Education, 5(4), 379-393. https://doi.org/10.12973/ejmste/75288

Koul, R. B. \& Fisher, D. (2002). Science classroom learning environments in India. In International Educational Research Conference of the Australian Association for Research in Education (AARE). Brisbane, Australia. Available at https://www.aare.edu.au/data/publications/2002/kou02003.pdf

Kuřina, F. (2014). Kompetence a školní praxe. Rozpaky oborového didaktika nad kurikulární reformou. Pedagogická orientace, 24(3), 433-442. https://doi.org/10.5817/PedOr2014-3-433

Lindahl, B. (2003). Pupils' responses to school science and technology? A longitudinal study of pathways to upper secondary school. Göteborg Studies in Educational Sciences, 196, 1-18. Available at https://gupea.ub.gu.se/bitstream/2077/9599/1/gupea_2077_9599_1.pdf

Lindner, M. (2014). Project learning for university students. In M. Rusek, D. Stárková (Eds.), Project-based Education in Science XI. (10-15). Praha: Pedagogická fakulta Univerzity Karlovy v Praze.

Lyons, T. (2006). Different countries, same science classes: Students' experiences of school science in their own words. International Journal of Science Education, 28(6), 591-613. https://doi.org/10.1080/09500690500339621

Matthews, M. R. (2011). Teaching the philosophical and worldview components of science - some considerations. In P. V. Kokkotas, K. S. Malamitsa \& A. A. Rizzaki (Eds.), Adapting historical knowledge production to the classroom (3-16). Rotterdam: Sense publishers.

MNE (Ministry of National Education of Poland). (2018). Nowa podstawa programowa (zkota podstawowa IV-VIII).

https://podstawaprogramowa.pl/Szkola-podstawowa-IV-VIII

MIZS (Ministry of Education, Science and Sport of the Republic of Slovenia). (2011a). Program osnova šola. Biologija. Učni načrt. Ljubljana. Available at http://www.mizs.gov.si/fileadmin/mizs.gov.si/pageuploads/podrocje/os/prenovljeni_UN/ UN_kemija.pdf

MIZS (Ministry of Education, Science and Sport of the Republic of Slovenia). (2011b). Program osnovna šola. Geografija - Učni načrt. Ljubljana: MIZS. Available at http://www.mizs.gov.si/fileadmin/mizs.gov.si/pageuploads/podrocje/os/prenovljeni_UN/ UN_geografija.pdf

MIZS (Ministry of Education, Science and Sport of the Republic of Slovenia). (2011c) Program osnovna šola. Naravoslovje - Učni načrt. Ljubljana: MIZS. Available at http://www.mizs.gov.si/fileadmin/mizs.gov.si/pageuploads/podrocje/os/prenovljeni_UN/ UN_naravoslovje.pdf

MIZS (Ministry of Education, Science and Sport of the Republic of Slovenia). (2014). Predmetnik osnovne šole. Available at http://www.mizs.gov.si/fileadmin/ mizs.gov.si/pageuploads/podrocje/os/devetletka/predmetniki/Pred_14_OS_4_12.pdf

MIZS (Ministry of Education, Science and Sport of the Republic of Slovenia). (undated) Predmetnik osnovne šole: Izbirni predmeti v osnovni šoli. Available at http://www.mizs.gov.si/si/delovna_podrocja/ 
direktorat_za_predsolsko_vzgojo_in_osnovno_solstvo/osnovno_solstvo/program/ izbirni_predmeti_v_osnovni_soli/\#c17861

MŠMT ČR (Ministerstvo školství, mládeže a tělovýchovy České republiky). (1997). Vzdělávací program Národni škola. Praha: SPN.

MŠMT ČR (Ministerstvo školství, mládeže a tělovýchovy Ceské republiky). (2003). Vzdělávací program Základni škola. Praha: Fortuna.

MŠMT ČR (Ministerstvo školství, mládeže a tělovýchovy České republiky). (2017). Rámcový vzdělávací program pro základni vzdělávání. Praha: MŠMT ČR. Available at http://www.msmt.cz/file/43792/

OECD. (2016). PISA 2015 results (Volume I): Excellence and equity in education. Paris: PISA, OECD Publishing, Paris. https://doi.org/10.1787/9789264266490-en

Osborne, J. \& Collins, S. (2001). Pupils' views of the role and value of the science curriculum: A focus-group study. International Journal of Science Education, 23(5), 441-467. https://doi.org/10.1080/09500690010006518

Osborne, J., Simon, S. \& Collins, S. (2003). Attitudes towards science: A review of the literature and its implications. International Journal of Science Education, 25(9), 1049-1079. https://doi.org/10.1080/0950069032000032199

Papáček, M. (2010). Badatelsky orientované př́rodovědné vyučování - cesta pro vzdělávání generací Y, Z a alfa? Scientia in educatione, 1(1), 33-49.

Park, M., Park, D. Y. \& Lee, R. E. (2009). A comparative analysis of Earth science curriculum using inquiry methodology between Korean and the US textbooks. Eurasia Journal of Mathematics, Science 83 Technology Education, 5(4), 395-411.

https://doi.org/10.29333/ejmste/108533

Pawilen, G. \& Sumida, M. (2005). A comparative analysis of the elementary science curriculum of Philippines and Japan. Bulletin of the Faculty of Education Ehime University, 52(1), 167-180.

Poupová, J. (2018). Výuka o vědě a jejích dějinách: Česko versus Západ. Orbis scholae, 12(1), 1-17. https://doi.org/10.14712/23363177.2018.281

Prokop, P. \& Fančovičová, J. (2017). The effect of hands-on activities on children's knowledge and disgust for animals. Journal of Biological Education, 51(3), 305-314. https://doi.org/10.1080/00219266.2016.1217910

Prokop, P., Prokop, M. \& Tunnicliffe, S. D. (2007). Is biology boring? Student attitudes toward biology. Journal of Biological Education, 42(1), 36-39.

https://doi.org/10.1080/00219266.2007.9656105

Radvanová, S., Čížková, V. \& Martinková, P. (2018). Mění se pohled učitelů na badatelsky orientovanou výuku? Scientia in educatione, 9(1), 81-103.

Randler, C., Hummel, E. \& Prokop, P. (2012). Practical work at school reduces disgust and fear of unpopular animals. Society $\&$ Animals, 20(1), 61-74.

https://doi.org/10.1163/156853012X614369

Rennie, L. J., Goodrum, D. \& Hackling, M. (2001). Science teaching and learning in Australian schools: Results of a national study. Research in Science Education, 31(4), 455-498. https://doi.org/10.1023/A:1013171905815

Russell, C. B. \& Weaver, G. C. (2011). A comparative study of traditional, inquiry-based, and research-based laboratory curricula: impacts on understanding of the 
nature of science. Chemistry Education Research and Practice, 12(1), 57-67. https://doi.org/10.1039/C1RP90008K

Schmidt, H., Machiels-Bongaerts, M., Hermans, H. H., Ten Cate, O., Venekamp, R. \& Boshuizen, H. H. (1996). The development of diagnostic competence: comparison of a problem-based, an integrated and a conventional medical curriculum. Academic Medicine, 71(6), 658-664.

Shirazi, S. (2017). Student experience of school science. International Journal of Science Education, 39(14), 1891-1912. https://doi.org/10.1080/09500693.2017.1356943

da Silva, C. S. D. S., Prochnow, T. R. \& Pellegrini, G. (2018). Z Generation youth and interest in science. Acta Scientiae, 20(6), 1056-1070.

https://doi.org/10.17648/acta.scientiae.v20iss6id4775

Stohr-Hunt, P. M. (1996). An analysis of frequency of hands-on experience and science achievement. Journal of Research in Science Teaching, 33(1), 101-109.

https://doi.org/10.1002/(SICI)1098-2736(199601)33:1\%3C101::AID-TEA6\%3E3.0.CO;2$\mathrm{Z}$

Straková, J. (2013). Jak dál s kurikulární reformou. Pedagogická orientace, 23(5), 734-744. https://doi.org/10.5817/PedOr2013-5-734

Su, Z., Su, J. \& Goldstein, S. (1994). Teaching and learning science in American and Chinese high schools: A comparative study. Comparative Education, 30(3), 255-270.

$\mathrm{Su}, \mathrm{Z}$., Su, J. \& Goldstein, S. (1995). Science education goals and curriculum designs in American and Chinese high schools. International Review of Education, 41(5), 371-388. https://doi.org/10.1007/BF01103035

Škoda, J. \& Doulík, P. (2009). Vývoj paradigmat př́rodovědného vzdělávání. Pedagogická orientace, 19(3), 24-44.

ŠPÚ (Štátny pedagogický ústav). (2015). Štátny vzdelávací program. Nižšie stredné vzdelávanie - 2. stupeň základnej školy. Appendix Biológia. Bratislava: Státny pedagogický ústav.

Šrgo, A. (2012). Scientific creativity: The missing ingredient in Slovenian science education. European Journal of Educational Research, 1(2), 127-141. https://doi.org/10.12973/eu-jer.1.2.127

Šorgo, A. \& Špernjak, A. (2009). Secondary school students' perspectives on and attitudes towards laboratory work in biology. Problems of Education in the 21st Century, 14, 123-134.

Šorgo, A. \& Śpernjak, A. (2012). Practical work in biology, chemistry and physics at lower secondary and general upper secondary schools in Slovenia. Eurasia Journal of Mathematics, Science 83 Technology Education, 8(1), 11-019.

https://doi.org/10.12973/eurasia.2012.813a

Štech, S. (2013). Když je kurikulární reforma evidence-less. Pedagogická orientace, 23(5), 615-633. https://doi.org/10.5817/PedOr2013-5-615

The Government of Hungary. (2014). The government's decree on the issue, introduction and implementation of the national core curriculum. Magyar Kölöny (official journal of Hungary). Available at http://regi.ofi.hu/download.php?docID $=5846$

Uitto, A. \& Kärnä, P. (2014). Teaching methods enhancing grade nine students' performance and attitudes towards biology. In C.P. Constantinou, N. Papadouris \& A. Hadjigeorgiou (Eds.), E-Book Proceedings of the ESERA 2013 Conference: Science 
education research for evidence-based teaching and coherence in learning (315-321). Nicosia, Cyprus: European Science Education Research Association.

van den Berg, E. (2013). The PCK of laboratory teaching: Turning manipulation of equipment into manipulation of ideas. Scientia in educatione, 4(2), 74-92.

Vařejka, P. (2006). Kabinet pro modernizaci výuky biologie? - Proč ne! Biologie Chemie Zeměpis, 15(5), 231.

White Wolf Consulting. (2009). Dưvody nezájmu žáků o př́rodovědné a technické obory. Výzkumná zpráva. Available at http://vzdelavani.unas.cz/duvody_nezajmu_obory.pdf

Zembylas, M. (2002) The global, the local, and the science curriculum: A struggle for balance in Cyprus. International Journal of Science Education, 24(5), 499-519. https://doi.org/10.1080/09500690110095267

Žoldošová, K. \& Prokop, P. (2006). Education in the field influences children's ideas and interest toward science. Journal of Science Education and Technology, 15(3-4), 304-313. https://doi.org/10.1007/s10956-006-9017-3

JANA POUPOVÁ, jana.poupova@natur.cuni.cz

VANDA JANŠTOVÁ, vanda.janstova@natur.cuni.cz

RADIM KUBA, radim.kuba@natur.cuni.cz

JAN MOUREK, jan.mourek@natur.cuni.cz

Charles University, Faculty of Science

Department of Teaching and Didactics of Biology

Viničná 7, 12843 Prague 2, Czech Republic 


\section{APPENDIX}

Differences between the biological parts of core curricula of selected countries (CZ, EST, HG, PL, SK, SLO)

\section{CURRICULAR DOCUMENTS}

CZ Rámcový vzdělávací program pro základní vzdělávání (MŠMMT ČR, 2017)

EST National Curriculum for Basic Schools (Government of the Republic of Estonia, 2014b) Appendix 4 of Regulation No 2 of the Government of the Republic of 6 January 2011. National Curriculum for Upper Secondary Schools (Last amendment 29 August 2014). Subject Field: Natural Science (Government of the Republic of Estonia, 2014a)

HG National Core Curriculum (The Government of Hungary, 2014)

PL Nowa podstawa programowa (Szkoła podstawowa IV-VIII) (MNE, 2018)

SK Státny vzdelávací program (ŠPÚ, 2015)

SLO Program osnovna šola. Biologija. Učni načrt. (MISZ, 2011a) Program osnovna šola. Naravoslovje - Učni načrt. (MISZ, 2011b)

\section{STAGE OF SCHOOL}

$\mathrm{CZ} 6^{\text {th }}$ to $9^{\text {th }}$ grades

EST $2^{\text {nd }}$ stage $\left(4^{\text {th }}\right.$ to $6^{\text {th }}$ grades $)$ and $3^{\text {rd }}$ stage $\left(7^{\text {th }}\right.$ to $9^{\text {th }}$ grades $)$

$\mathrm{HG} \quad 5^{\text {th }}$ to $8^{\text {th }}$ grades

$\mathrm{PL} \quad 4^{\text {th }}$ to $8^{\text {th }}$ grades

SK $5^{\text {th }}$ to $9^{\text {th }}$ grades

SLO $2^{\text {nd }}$ stage $\left(4^{\text {th }}\right.$ to $6^{\text {th }}$ grades $)$ and $3^{\text {rd }}$ stage $\left(7^{\text {th }}\right.$ to $9^{\text {th }}$ grades $)$, relevant subjects taught from the $6^{\text {th }}$ to the $9^{\text {th }}$ grades

\section{INTEGRATED SCIENCE OR SEPARATE BIOLOGY}

$\mathrm{CZ}$ It depends on the school, both arrangements are possible.

EST From $4^{\text {th }}$ to $7^{\text {th }}$ grades science integrating biology, chemistry, geography and physics is taught. From $7^{\text {th }}$ grade biology is taught.

HG Integrated science is being planned, but in the document separate subjects are dealt with.

PL Biology, science in $4^{\text {th }}$ grade.

SK Biology.

SLO In the $6^{\text {th }}$ and $7^{\text {th }}$ grades science (naravoslovje), integrating biology, chemistry, physics, environmental science and geology; in the $8^{\text {th }}$ and $9^{\text {th }}$ grades separate biology (biologija).

\section{PRESCRIBED TIME ALLOCATION}

CZ For the educational area Man and nature (comprised of biology, chemistry, geography and physics) the time allocation pooled for $6^{\text {th }}$ to $9^{\text {th }}$ grades must be at least 21 lessons per week. This educational area should be incorporated in each grade.

EST In the $2^{\text {nd }}$ stage science should be taught 7 lessons per week, in the $3^{\text {rd }}$ stage (in $7^{\text {th }}$ grade) science should be taught 2 lessons per week and biology 5 lessons per week.

HG Minimum percentage rates for subject areas are set:

a) Man and nature - for $5^{\text {th }}$ and $6^{\text {th }}$ grades $6-10 \%$; for $7^{\text {th }}$ and $8^{\text {th }}$ grades $10-15 \%$. 
b) The Earth - our environment - for $5^{\text {th }}$ and $6^{\text {th }}$ grades $6-10 \%$; for $7^{\text {th }}$ and $8^{\text {th }}$ grades $15-20 \%$.

PL It is not specified.

SK It is not specified.

SLO science: $6^{\text {th }}$ grade -2 lessons per week (70 per school year), $7^{\text {th }}$ grade -3 lessons per week (105 per school year), 175 lessons in total biology: $8^{\text {th }}$ grade 1.5 lessons per week ( 52 per school year), $9^{\text {th }}$ grade -2 lessons per week (64 per school year), 116 lessons in total.

\section{OBJECTIVES AND EXPECTED OUTCOMES}

The main aim is to develop scientific literacy. Forming scientific literacy is comprised of gaining methodological skills (exploring, problem solving, dealing with information, discussing), forming a positive attitude to science and wildlife and gaining environmentallyfriendly attitudes. Expected outcomes are formulated as verbs that show what ability pupils should obtain.

\section{DiSTRIBUTION OF SUBJECT MATTER INTO GRADES}

CZ Distribution of subject matter into grades is decided on the school level.

EST Subject matter is obligatorily distributed into stages, not into particular grades.

HG Subject matter is divided into two sections: $5^{\text {th }}$ and $6^{\text {th }}$, and $7^{\text {th }}$ and $8^{\text {th }}$ grades. It is not obligatory.

PL Distribution of subject matter is suggested but is not obligatory.

SK Distribution of subject matter into grades is fixed.

SLO Distribution of subject matter into grades is fixed.

\section{STRUCTURING OF SUBJECT MATTER}

CZ Structuring of the subject matter is decided on the school level. In the document it is arranged into separate biological disciplines (botany, zoology, ....).

EST The second stage science follows an ecological approach. The third stage of biology deals with particular taxa (e.g., physiology and reproduction of vertebrates), ecology, human biology, genetics and evolutionary biology. The third stage science is devoted especially to physics and chemistry.

HG An ecological approach to the subject matter is followed.

PL Structuring of the subject matter follows traditional biological disciplines. It is similar to the Czech one.

SK The subject matter in $5^{\text {th }}$ grade follows an ecological approach, then anatomy and physiology of various taxa of organisms is dealt with. In higher grades, human biology, genetics, ecology and geology are taught.

SLO A holistic approach to biological teaching contents, three hierarchical levels - cell, organism and ecosystem, from the $6^{\text {th }}$ to the $9^{\text {th }}$ grades. $6^{\text {th }}$ grade focuses mainly on the biology of plants; $7^{\text {th }}$ grade on the biology of bacteria, fungi, animals and ecosystems; $8^{\text {th }}$ grade on cell biology and human biology. $9^{\text {th }}$ grade on synthesizing and applied topics, such as evolution, genetics, biotechnologies, biodiversity or biology and human society.

\section{DEPTH OF LEARNING CONTENT}

CZ The particular species pupils should know are not specified. Learning content is described only briefly. Classes of vertebrates, phyla of invertebrates and plants and organ systems are enumerated. 
EST Learning content is described briefly, the document enumerates a few concepts and a list of concrete practical tasks (together with the use of ICT) for each topic.

HG Learning content is not described in detail. No taxa are specified.

PL Learning content is short and briefly described. Classes of vertebrates, phyla of invertebrates and plants, organ systems and selected diseases are enumerated.

SK Learning content is short and briefly described. Classes of vertebrates, phyla of invertebrates and plants and organ systems are enumerated.

SLO Subject matter is briefly described. Classes of vertebrates, phyla of invertebrates and plants and organ systems are enumerated. A strong emphasis is put on the pupils' understanding of the relation between different hierarchical levels and between the structure and function, e.g., the anatomy of organs, their physiological function and human health.

\section{INCORPORATION OF GEOLOGY}

$\mathrm{CZ}$ Yes.

EST There are just a few geological issues in science and biology, the majority of them is incorporated into geography.

HG There are just a few geological issues in the chapter Earth.

PL There are just a few geological issues in biology.

SK Yes.

SLO Briefly covered by the teaching content "Rocks and soil" in the $6^{\text {th }}$ grade.

\section{EDUCATIONAL AND PRACTICAL AIMS}

They are related to food, healthy lifestyle, first aid, agriculture, wildlife protection and protection of humans in extraordinary situations.

\section{OPPORTUNITY TO AFFECT WHAT IS TAUGHT}

CZ It is not mentioned at all.

EST There is just one general notion.

HG It is not mentioned at all.

PL It is not mentioned at all.

SK It is not mentioned at all.

SLO Teachers are allowed to use up to $20 \%$ of time allocation in the $8^{\text {th }}$ and $9^{\text {th }}$ grades for more detailed teaching of topics according to the pupils' abilities and interests, current issues or the local situation.

\section{TAXONOMIC DEMANDS}

CZ There are a few remarks on principles of classification.

EST It is not mentioned at all.

HG There are a few remarks on principles of classification.

PL There are a few remarks on principles of classification.

SK There are a few remarks on classifying species into taxa. Botany and zoology is not treated systematically.

SLO Botany and zoology are not treated in a systematic manner, knowledge of taxonomic principles is required. 


\section{INCORPORATION OF EVOLUTION}

CZ Evolutionary biology is not a separate chapter, evolutionary issues are incorporated into other chapters (for example, human evolution is incorporated into human bio$\log$ ).

EST In the $3^{\text {rd }}$ stage there is a separate chapter on evolutionary biology. It does not penetrate other chapters.

HG There are brief and general notions about the necessity of acquainting pupils with the Theory of Evolution.

PL There is a separate chapter about the evolution of life. It includes similarities between humans and apes.

SK Only one topic (the origin of life and its evolution) is mentioned in general. There is no notion about the evolution of humanity.

SLO One of the crucial themes of the $9^{\text {th }}$ grade; treated as a separate chapter. Evolution is recognised as a central principle in biology.

\section{TREATING ECOLOGY}

CZ Ecology of species is incorporated into systematic chapters dealing with taxa. There is a separate chapter ecology. (Nonetheless, the arrangement of subject matter is not obligatory.)

EST The $2^{\text {nd }}$ stage deals with ecosystems, in the $3^{\text {rd }}$ stage ecology and environmental protection is dealt with in biology.

HG The whole $2^{\text {nd }}$ stage is ecologically-oriented.

PL There are separate chapters ecology and environment.

SK The $5^{\text {th }}$ grade is ecologically oriented. It deals with ecosystems and organisms living with humans and in human settlements. In the $8^{\text {th }}$ grade environmental protection and ecology is dealt with.

SLO Ecological topics start in the $6^{\text {th }}$ grade with the roles of plants in ecosystems; continue in the $7^{\text {th }}$ grade with the ecological roles of animals, bacteria and fungi and with the structure and functioning of ecosystems and ends in the $9^{\text {th }}$ grade with biomes and biosphere and biodiversity.

\section{TREATING CELL BIOLOGY}

CZ Some topics are included in introduction to biology, the rest is distributed in many other chapters. (Nonetheless, the arrangement of subject matter is not obligatory.)

EST Subject matter concerning the cell is divided into several chapters.

HG Subject matter concerning the cell is divided into several chapters.

PL The majority of cell biology is incorporated into the introductory chapter Organisation and chemistry of life. The rest is divided into other chapters.

SK Subject matter concerning the cell is divided into several chapters. (The sequence of the partial topic is the following: structure of cell, function of cell, specifics of bacterial cell, eukaryotic nucleus.

SLO Cell biology is taught from the $6^{\text {th }}$ up to the $9^{\text {th }}$ grades - starting with plant cells, continuing with animal, bacterial and fungal cells and finishing with general topics such as cell physiology and genetics.

\section{INCORPORATION OF HISTORY OF SCIENCE}

CZ There is only an isolated notion about important biologists and their discoveries.

EST It is not mentioned at all.

HG It is mentioned just in a general manner. 
PL It is not mentioned at all.

SK It is not mentioned at all.

SLO Teachers should present biological facts as the result of the work of many scientists throughout centuries of research. The significance of some biological discoveries is mentioned (e.g., Darwin's Theory of Evolution or the structure of DNA).

\section{RELATIONSHIP BETWEEN SCIENCE AND SOCIETY}

CZ Specification of the subject matter is comprised of, among others, such points as importance, protection, usage, benefits, risks, advantages and disadvantages.

EST The document stresses the need of responsibility for the environment, a positive relationship to wildlife and understanding of the connections between science and technology.

HG The document stresses the need of responsibility, of being able to distinguish between pseudoscientific and scientific approaches and of understanding the links between science and technology.

PL The document mentions the need of understanding connections between science and everyday life (for example, in medical issues) and between various scientific disciplines. It stresses understanding problems concerning GMO, biodiversity, energy sources, etc.

SK Some chapters deal with agriculture, forestry, medicine and environmental protection.

SLO The document stresses the need of responsibility for the environment, positive relationship to wildlife and understanding of the connections between science and technology.

\section{EMPHASIS ON LOCAL REGIONS}

$\mathrm{CZ}$ It is not mentioned at all.

EST It is accented especially in $2^{\text {nd }}$ stage science which focuses on the school surroundings, Estonia and the Baltic region. Pupils should be occupied with the environmental problems of their home region.

HG Pupils should occupy themselves with the environment in school surroundings and they should know the species living there.

PL Pupils should be acquainted with the species living near their home.

SK The document lists concrete environmental tasks pupils should do in their school surroundings. They focus on the knowledge of local natural specifics.

SLO The pupils should understand the reasons for the high biodiversity of Slovenian nature.

\section{INTERDISCIPLINARY LINKS AND THEIR FULFILMENT}

CZ Creating interdisciplinary links is required only in general, no concrete advice is given.

EST The connection between biology or science and key competences is briefly mentioned. There are several pieces of advice for teachers on how to create interdisciplinary links in their lessons. This is made easier by the existence of integrated science.

HG The requirement is stated only in general, no concrete advice is given.

$\mathrm{PL}$ The requirement is stated only in general, no concrete advice is given.

SK Creating interdisciplinary links is required only in general, no concrete advice is given.

SLO The connection between biology or science and key competences is briefly mentioned. There are several pieces of advice for teachers on how to create interdisciplinary links 
in their lessons. This is made easier by the existence of integrated science in the $6^{\text {th }}$ and $7^{\text {th }}$ grades.

\section{RELATED EDUCATIONAL AREAS AND CROSS-CURRICULUM SUBJECTS}

CZ Man and health, Man and work, Ethical education, Environmental education

EST Environment and sustainable development, Health and safety

HG Way of life - practical skills, Earth - our environment

PL No related educational area is mentioned.

SK Man and work, Health and movement, Environmental education, Protection of life and health, Education for marriage and parenthood.

SLO Human influence on nature and the environment, Biology and society, Chemistry of living systems, Biotechnology, Biomes and the biosphere, Protection of nature and the environment. Interdisciplinary links and links between biology and human health are often mentioned in particular topics.

\section{RECOMMENDED TEACHING METHODS}

CZ Problem-based learning and the pupils' own activities should be accented. However, no concrete methods are recommended.

EST The document requires the usage of various methods, including homework, work in pairs and groups, role playing, outdoor activities, discussion, project-based education, creating portfolios and research papers and practical lessons. Lessons should be pupil-centred, active, and pupils should occupy themselves with problem-solving. In the $2^{\text {nd }}$ stage, pupils should visit a centre for environmental education at least twice a year, on the $3^{\text {rd }}$ stage they should do field work, go to a museum or to a laboratory at least once in each science subject.

HG It is stated that teaching methods should be various and should involve experiments.

$\mathrm{PL} \quad$ It is recommended to present information in various ways (pictures, films, texts, ... ), and to do field work and experiments.

SK The document recommends problem-based education; creating mental maps is mentioned several times.

SLO Didactic recommendations are included as well elaborated separate chapters. Besides particular teaching methods, they include also general topics, such as remedying the pupils' misconceptions or promoting their interest in biology.

\section{SPECIFIC BIOLOGICAL SKILLS}

CZ Pupils should observe with a magnifying glass, microscope or telescope. They should use various determination materials, create a herbarium and dissect plants and animals.

EST The document describes methodological skills in general; concrete tasks (such as using a microscope, doing field work, ...) are described in passages. Practical work and use of ICT.

HG Pupils' skills are described only in general. Being able to use a microscope is the only concrete demand.

PL Methodological skills are mentioned in general as is using a microscope, observations and doing field work.

SK Specific biological skills are formulated similarly to the Czech version. Moreover, in the Slovakian document there is mentioned at least one other research activity linked to some presentation skill (making a poster, discussing conclusions, ... ). 
SLO Methodological (inquiry) skills are mostly mentioned in general, without links to particular biological topics. Use of a microscope is required in relation to human and animal cells and tissues and the circulatory system (recognition of blood cell types).

\section{PUBLIC ENGAGEMENT}

CZ It is not mentioned at all.

EST The pupils' public engagement is required but not so strongly as in Slovakia.

HG It is not mentioned at all.

PL Just the understanding of the social aspects of science is mentioned, no pupils' activities in this respect is required.

SK The pupils' public engagement is required in connection with environmental protection, health protection and local regions.

SLO Responsible personal behaviour in relation to the protection of nature and environment and the adoption of principles of sustainable development are required.

\section{MINIMUM NUMBER OF REQUIRED PRACTICAL LESSONS}

CZ It is not mentioned at all.

EST In each chapter, the practical tasks pupils should do are specified. Among the teaching forms and methods, outdoor activities and field work is required.

HG In the $5^{\text {th }}$ and $6^{\text {th }}$ grades at least 2 experiments or observations and 4 presentations of some results should be made. In the $7^{\text {th }}$ and $8^{\text {th }}$ grades there should be at least 4 experiments, and the creation of 4 protocols, 1 health project and 1 practical work outside school.

$\mathrm{PL} \quad$ It is not mentioned at all.

SK It is not mentioned at all.

SLO At least $40 \%$ of teaching hours in the $6^{\text {th }}$ and $7^{\text {th }}$ grades must be is based on methods of practical work, with an emphasis on classroom and field experimental research. In the $8^{\text {th }}$ grade at least 10 and in the $9^{\text {th }}$ grade at least 13 teaching hours of biology ( $20 \%$ of the total time allocation) must be devoted to experiments and fieldwork in smaller groups.

\section{SPECIFICATION OF PRACTICAL TASKS}

CZ It is not mentioned at all.

EST It is specified in each chapter in a part called Practical work and use of ICT.

HG Tasks for practical lessons are not specified.

PL In some chapters it is stated that experiments should be done, however no concrete experiments are mentioned.

SK Practical lessons are not described in detail, but the activities required can be inferred from the expected outcomes.

SLO Tasks for practical lessons are not specified.

\section{REQUIREMENT OF METHODOLOGICAL SKILLS}

Much attention is paid to this issue. Especially the ability to observe, measure, experiment, create a hypothesis, analyse results, draw conclusions and present them is required. 


\section{EQUIPMENT OF LABORATORIES AND SPECIAL CLASSROOMS}

$\mathrm{CZ}$ It is mentioned just in general. (The school should have adequate special classrooms.)

EST More concrete requirements on classroom equipment are stated.

HG It is not mentioned at all.

PL Concrete requirements on classroom equipment as well as on requisites (models of organs, ...) are dealt with.

SK It is mentioned just in general. (The school should have adequate special classrooms.)

SLO Not specified in detail.

\section{SPECIFICATION OF ASSESSMENT}

$\mathrm{CZ} \quad$ It is not mentioned at all.

EST It is specified in detail. The document states, for example, what percentage a particular ability should have in final marks.

HG It is not mentioned at all.

$\mathrm{PL} \quad$ It is not mentioned at all.

SK It is not mentioned at all.

SLO Three standards of knowledge are distinguished (standard 1 - minimum level, standard 3 - most advanced level of knowledge). The standards are not based on details of the learning content, but on understanding principles, ability to use knowledge in a broader context, proper interpretation of facts and taking stances on issues based on relevant arguments. 